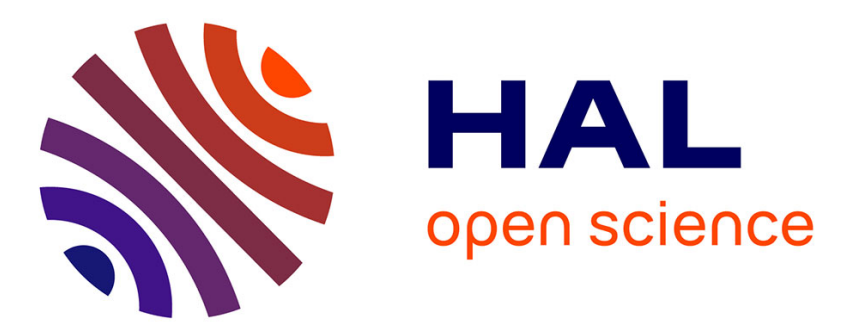

\title{
A NEW GENERATION OF LASER ACTIVE IONS FOR TUNABLE LASER OPERATION : THE TRANSITION - METAL IONS IN TETRAHEDRAL COORDINATION
}

\author{
H. Manaa, R. Moncorge
}

\section{To cite this version:}

H. Manaa, R. Moncorge. A NEW GENERATION OF LASER ACTIVE IONS FOR TUNABLE LASER OPERATION : THE TRANSITION - METAL IONS IN TETRAHEDRAL COORDINATION. Journal de Physique IV Proceedings, 1991, 01 (C7), pp.C7-331-C7-334. 10.1051/jp4:1991788 . jpa-00251031

\section{HAL Id: jpa-00251031 https://hal.science/jpa-00251031}

Submitted on 1 Jan 1991

HAL is a multi-disciplinary open access archive for the deposit and dissemination of scientific research documents, whether they are published or not. The documents may come from teaching and research institutions in France or abroad, or from public or private research centers.
L'archive ouverte pluridisciplinaire HAL, est destinée au dépôt et à la diffusion de documents scientifiques de niveau recherche, publiés ou non, émanant des établissements d'enseignement et de recherche français ou étrangers, des laboratoires publics ou privés. 


\title{
A NEW GENERATION OF LASER ACTIVE IONS FOR TUNABLE LASER OPERATION: THE TRANSITION - METAL IONS IN TETRAHEDRAL COORDINATION
}

\author{
H. MANAA and R. MONCORGE \\ Laboratoire de Physico-Chimie des Matériaux Luminescents, Université de Lyon I, UA 442 CNRS, \\ F-69622 Villeurbanne cedex, France
}

\begin{abstract}
We report the polarized absorption spectra, and the emission or stimulated emission cross-section spectra of several $\mathrm{Cr}^{4+}, \mathrm{Mn}^{5+}$ and $\mathrm{Co}^{2+}$ doped crystals. The emission lifetimes as a function of temperature are repported as well.
\end{abstract}

The absorption characteristics of many inorganic materials doped with transition-metal ions have been often discovered a long time before their fluorescence properties. This is due sometimes to misinterpretations of the spectra which have led to investigations in wavelength domains where nothing should appear or to technical barriers linked for example to the difficulty to register infrared spectra at a time where the detectors were not sensitive enough.

Now a number of these crystals have been lased efficiently or have been studied for their potential laser properties. In the last decade, it has been the case of materials doped with transitionmetal ions such as $\mathrm{Ti}^{3+}, \mathrm{Cr}^{3+}, \mathrm{V}^{2+}, \mathrm{Co}^{2+}$ and $\mathrm{Ni}^{2+}$ and a number of them such as alexandrite $\left(\mathrm{BeAl}_{2} \mathrm{O}_{4}: \mathrm{Cr}^{3+}\right), \mathrm{Ti}:$ saphir $\left(\mathrm{Al}_{2} \mathrm{O}_{3}: \mathrm{Ti}^{3+}\right)$ and $\mathrm{MgF}_{2}: \mathrm{Co}^{2+}$ are now commercialy available. However in these systems, the active ions site in nearly octahedral environments so that the crosssections of the optical transitions are relatively weak $\left(10^{-21}-10^{-19} \mathrm{~cm}^{2}\right)$ wich make them relatively low gain media. That is why the search in this domain still remains very active. In particular, in the recent years, a new solution has appeared with the tetrahedrally coordinated transition-metal ions. In this case the optical transitions can be electric-dipole allowed thus give rise to larger emission crosssections $\left(10^{-19}-10^{-17} \mathrm{~cm}^{2}\right)$ and possibly higher gain materials. This applies to the now famous $\mathrm{Cr}^{4+}$ doped forsterite $\left(\mathrm{Mg}_{2} \mathrm{SiO}_{4}\right)\left({ }^{1}\right)$ and might be the case of the recently discovered $\left.{ }^{2}\right) \mathrm{Mn}^{5+}$ doped spodiosite $\left(\mathrm{A}_{2}\left(\mathrm{PO}_{4}\right) \mathrm{B}\right)$ and apatite $\left(\mathrm{A}_{2}\left(\mathrm{PO}_{4}\right)_{3} \mathrm{~B}\right)$ crystals $(\mathrm{A}=\mathrm{Ca}, \mathrm{Sr} \mathrm{B}=\mathrm{Cl}, \mathrm{F})$. In this paper, we present the main spectroscopic and fluorescence data of such systems.

The two $3 \mathrm{~d}^{2}$ ions $\mathrm{Cr}^{4+}$ and $\mathrm{Mn}^{5+}$ doped systems are characterized by an interesting emission band - figure 1 to 3 - around $1200 \mathrm{~nm}$, due in the case of $\mathrm{Mg}_{2} \mathrm{SiO}_{4}: \mathrm{Cr}^{4+}$ to the ${ }^{3} \mathrm{~T}_{2}-{ }^{3} \mathrm{~A}_{2}$ transition, and to ${ }^{1} \mathrm{E}-{ }_{-}{ }^{3} \mathrm{~A}_{2}$ transition in the case of $\mathrm{Mn}^{5+}$ doped systems. Their fluorescence lifetimes and their temperature dependence are given in figure 6.

In the case of $\mathrm{Co}^{2+}$ doped $\mathrm{LGO}\left(\mathrm{LiGa}_{5} \mathrm{O}_{8}\right)$ or LMA ( $\left.\mathrm{La} \mathrm{MgAl}_{11} \mathrm{O}_{19}\right)$ - figure 4-5 - we observe three emission bands around 700,900 , and 1100 or $1200 \mathrm{~nm}$. The calculated stimulated emission cross- section is about $2.410^{-17} \mathrm{~cm}^{2}$ at $690 \mathrm{~nm}$ in LGO : $\mathrm{Co}^{2+}$ and $1.610^{-18} \mathrm{~cm}^{2}$ at 670 $\mathrm{nm}$ in LMA : $\mathrm{Co}^{2+}$. Nevertheless, the fluorescence lifetime in these two systems is relatively short figure. 7 -, and decreases drastically with increasing temperature in the case of LMA :Co ${ }^{2+}$, and its room temperature quantum efficiency is certainly low. 

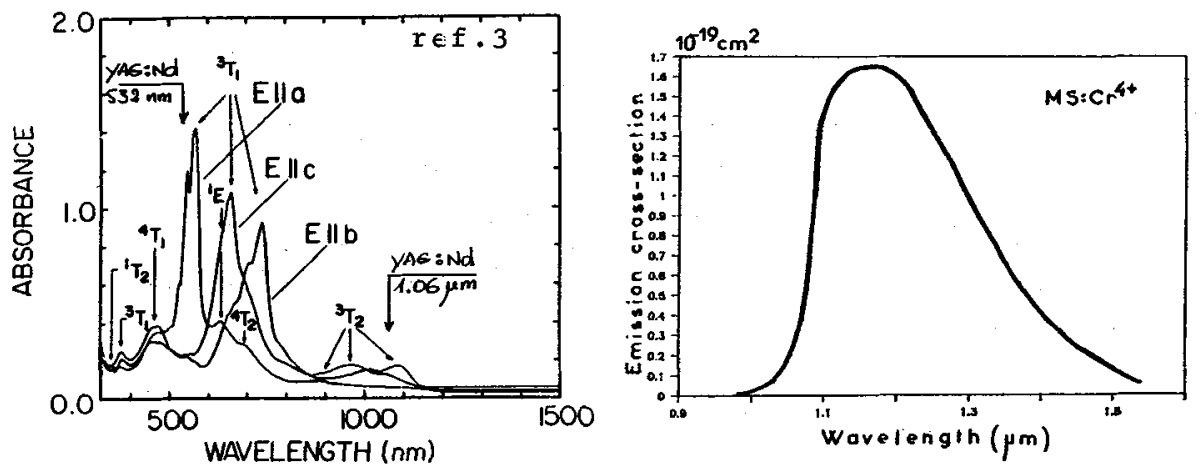

Fig.1. Room temperature polarized absorption and stimulated emission cross-section of

$$
\mathrm{MS}\left(\mathrm{MgSi}_{2} \mathrm{O}_{4}\right): \mathrm{Cr}^{4+} \text {. }
$$
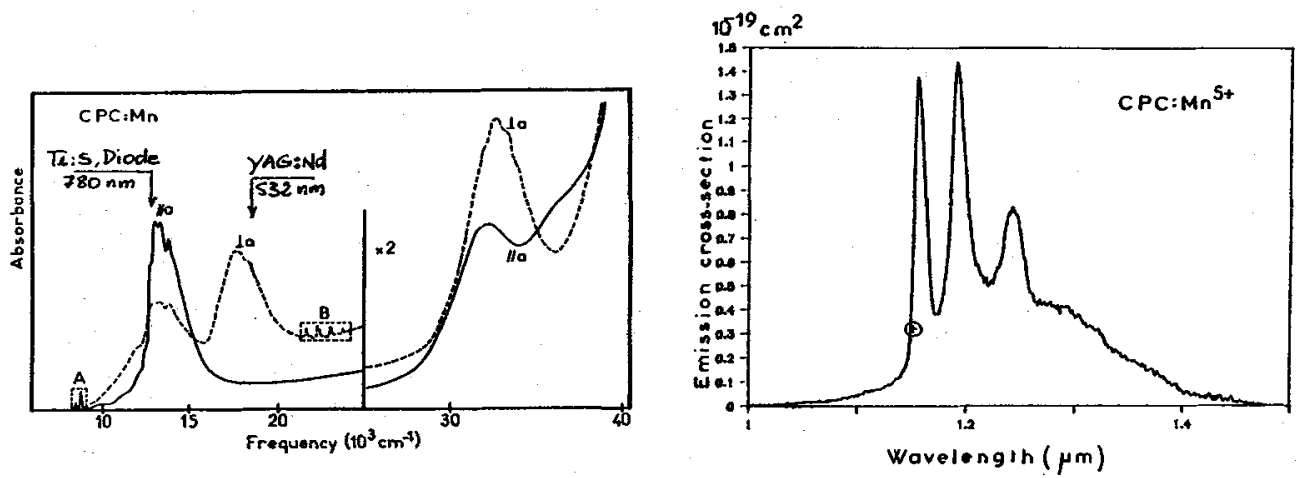

Fig.2. Low temperature polarized absorption and room temperature stimulated emission cross-section of $\mathrm{CPC}\left(\mathrm{Ca}_{2} \mathrm{PO}_{4} \mathrm{Cl}\right): \mathrm{Mn}^{5+}$.
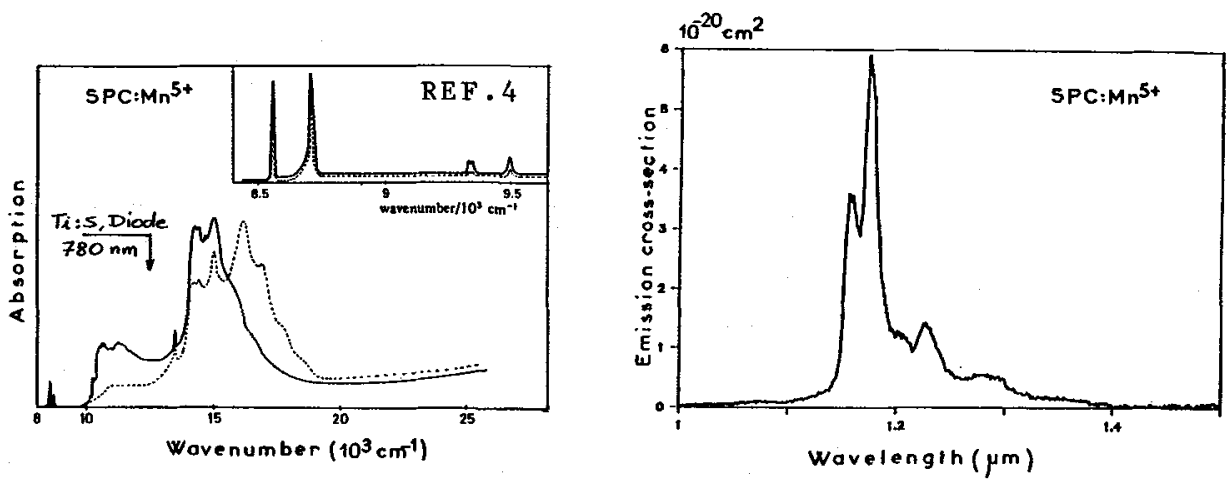

Fig.3. Low temperature polarized absorption and room temperature stimulated emission cross-section of

$$
\mathrm{SPC}\left(\mathrm{Sr}_{5}\left(\mathrm{PO}_{4}\right)_{3} \mathrm{Cl}\right): \mathrm{Mn}^{5+} \text {. }
$$




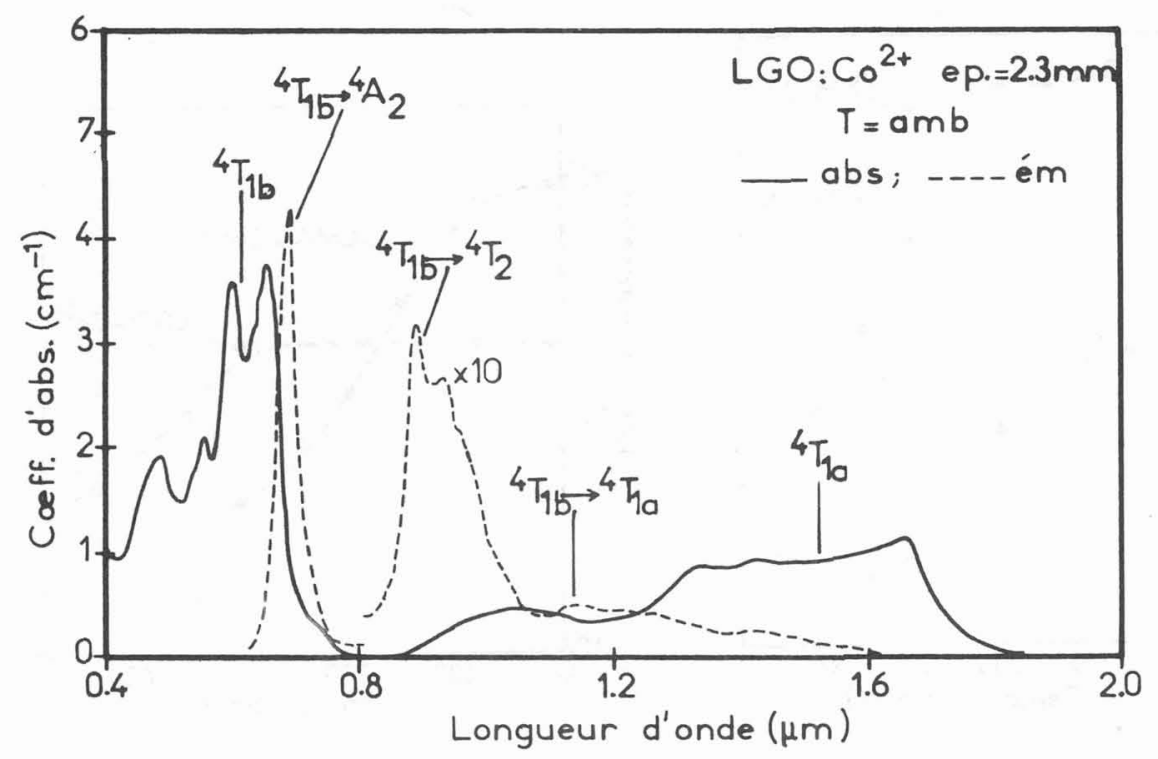

Fig.4. Absorption and emission spectra of $\mathrm{LGO}\left(\mathrm{LiGa}_{5} \mathrm{O}_{8}\right): \mathrm{Co}^{2+}$ at room temperature.

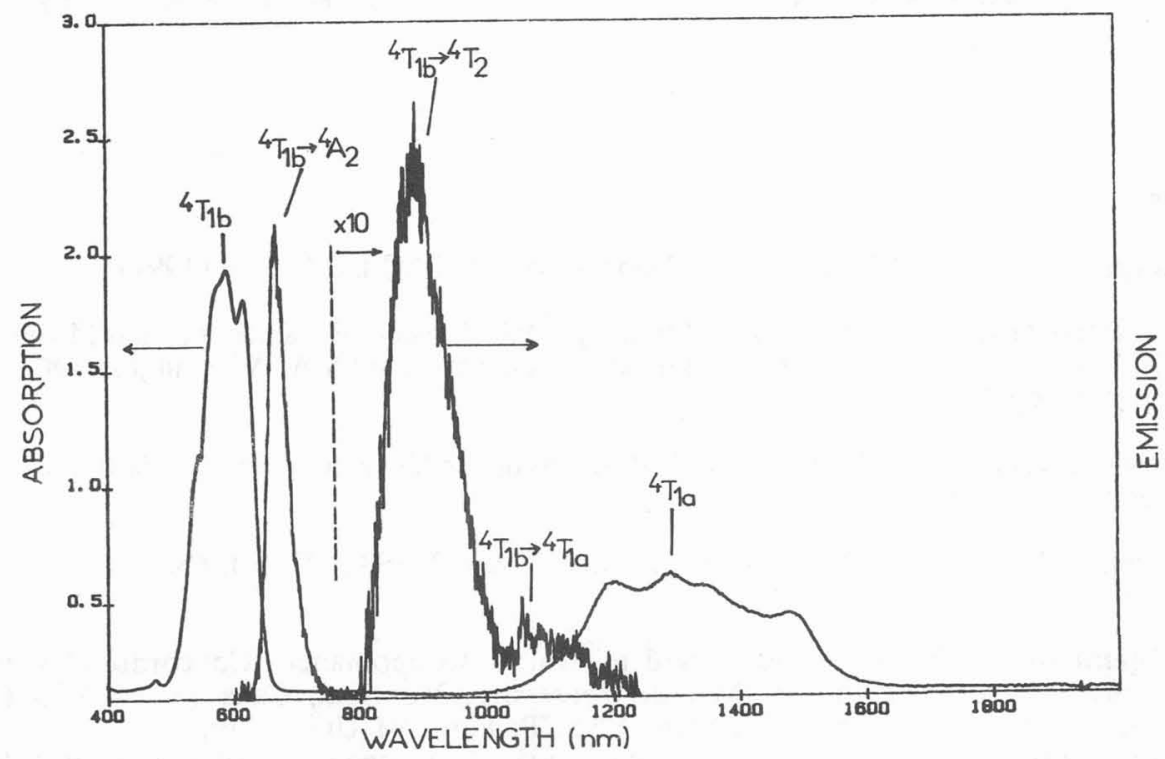

Fig.5. Absorption and emission spectra of $\operatorname{LMA}\left(\operatorname{LaMgAl}{ }_{11} \mathrm{O}_{19}\right): \mathrm{Co}^{2+}$ at room temperature. 


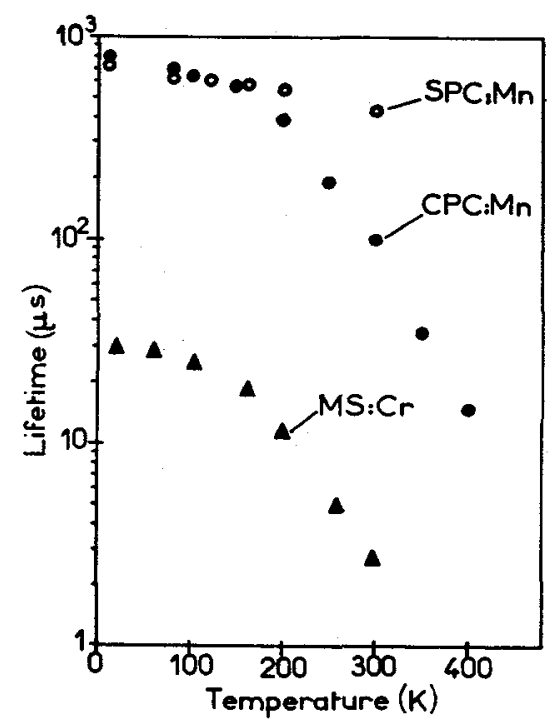

Fig.6. Temperature dependence of the fluorescence lifetime in CPC: $\mathrm{Mn}^{5+}(\bullet)$, SPC:Mn ${ }^{5+}(0)$ and $\mathrm{MS}: \mathrm{Cr}^{4+}(\Delta)$.

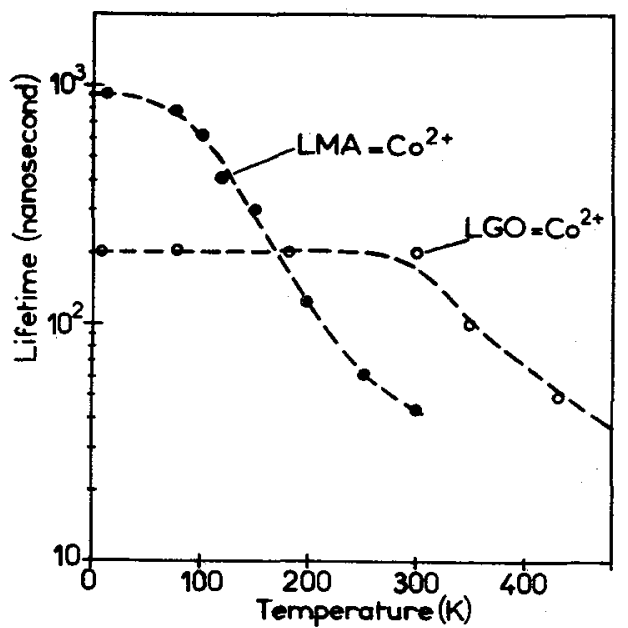

Fig.7. Temperature dependence of the fluorescence lifetime in LMA : $\mathrm{Co}^{2+}$ (•) and LGO :Co ${ }^{2+}$ (o).

\section{References :}

/1/ R.Moncorge, G.Cormier, D.J.Simkin, J.A.Capobianco, IEEE J.Q.E 27, 114 (1991).

/2/ J.A.Capobianco, G.Cormier, H.Manaa, R.Moncorge, P.Galarneau, B.Labranche, and M.Bettinelli in Advanced Solid State Lasers 1991 Technical Digest series (O.S.A, Washington DC 1991) Postdealine paper. pdp 2.

13/ V.Petricevic, S.K.Gayen, R.R.Alfano; OSA Proceedings on Tunable solid-state lasers; ed. M.L. Shand, H.P Jenssen; vol. 5, p 77 (1989).

/4/ R.Borromei, L.Olcari, P.Day; J. Chem. Soc. Faraday Trans. 2 (1981) 77, p 1563.

Acknowledgements : Thanks are expressed to Prof. J.A.Capobianco (Concordia University, Montreal, Canada), Prof. D.J.Simkin (McGill University, Montreal, Canada), J.C.Vial (LSP, Grenoble University, France), Prof. D.Vivien (ENSCP, Paris VI University, France) and their coworkers for their help in collecting some of the data and/or for having provided us with the different single crystals. 